\title{
EKSPERIMENTAL PERBANDINGAN KEKUATAN TEKAN KARAKTERISTIK BETON SELF COMPACTING MENGGUNAKAN AGREGAT KASAR ALAMI DAN AGREGAT KASAR DAUR ULANG
}

\author{
Martinus Pramanata Sapeai $^{1, \bigotimes)}$, Johannes Adhijoso Tjondro ${ }^{2)}$ \\ 1,2 Jurusan Teknik Sipil, Fakultas Teknik, Universitas Katolik Parahyangan \\ E-mail: martinus22mps@gmail.com
}

\begin{abstract}
Utilization of recycled concrete waste as an alternative to natural coarse aggregates in this experiment is in accordance with the concept of sustainable construction. Concrete is the main material of structural elements most commonly used in general construction and has properties that are difficult to recycle by themselves naturally. Nowdays concrete innovation with the concept of self compacting (SCC) is widely used especially in high rise building and buildings with special specification. SCC has high flowability properties so that it can flow and compact themselves, but in SCC with normal quality still need compactor. The concept of making test specimens is in accordance with real conditions in the field, where aggregates do not go through a cleaning process. There are four different mix design with the required specified compressive strength of $20 \mathrm{MPa}$. Mix design 1A (natural coarse aggregates) and $1 B$ (recycled coarse aggregates) has a maximum aggregate size $12.50 \mathrm{~mm}$, and mix design $2 A$ (natural coarse aggregates) and $2 B$ (recycled coarse aggregates) has a maximum aggregate size $19.00 \mathrm{~mm}$. This experimental results in specified compressive strength concrete for mix design $1 \mathrm{~A}, 1 \mathrm{~B}, 2 \mathrm{~A}$, and $2 \mathrm{~B}$ as follows: 30.93 MPa, 26.21 MPa, 29.37 MPa and 26.43 MPa. Therefore, recycled concrete aggregates can be alternative to natural coarse aggregates and can also be made into concrete with the SCC concept.
\end{abstract}

Keywords: Recycled Coarse Aggregates, Self Compacting Concrete, Specified Compressive Strength Concrete

\begin{abstract}
ABSTRAK
Pemanfaatan limbah beton yang telah didaur ulang sebagai alternatif pengganti agregat kasar alami dalam eksperimental ini sesuai dengan konsep konstruksi berkelanjutan. Beton adalah material utama elemen struktur yang paling banyak digunakan pada konstruksi umum dan memiliki sifat yang sulit terdaur ulang dengan sendirinya secara alami. Dewasa ini inovasi beton dengan konsep self compacting (SCC) banyak digunakan terutama pada bangunan bertingkat tinggi dan bangunan dengan spesifikasi khusus. SCC memiliki sifat flowability yang tinggi sehingga mampu mengalir dan memadat sendiri, tetapi pada SCC dengan mutu normal masih memerlukan alat pemadat. Konsep pembuatan benda uji sesuai kondisi ril di lapangan, di mana agregat tidak melalui proses pembersihan. Terdapat empat mix design berbeda dengan kekuatan tekan karakteristik yang disyaratkan masing-masing 20 MPa. Mix design 1A (agregat kasar alami) dan 1B (agregat kasar daur ulang) memiliki ukuran agregat maksimum $12.50 \mathrm{~mm}$, serta mix design 2A (agregat kasar alami) dan 2B (agregat kasar daur ulang) ukuran agregat maksimum $19.00 \mathrm{~mm}$. Eksperimental ini menghasilkan kekuatan tekan karakterisik beton untuk mix design 1A, 1B, 2A, dan 2B sebagai berikut: 30.93 MPa, 26.21 MPa, 29.37 MPa dan 26.43 MPa. Dengan demikian, limbah beton yang telah didaur ulang dapat menjadi alternatif pengganti agregat kasar alami serta dapat juga dijadikan beton dengan konsep SCC.
\end{abstract}

Kata Kunci: Agregat Kasar Daur Ulang, Self Compacting Concrete, Kekuatan Tekan Karakteristik Beton 


\section{PENDAHULUAN}

Dewasa ini pertumbuhan penduduk di Indonesia meningkat pesat. Hal ini menyebabkan peningkatan terhadap kebutuhan akan fasilitas ruang guna melakukan aktivitas sehari-hari. Banyaknya pembangunan maka secara tidak langsung industri konstruksi berkontribusi menghasilkan limbah konstruksi. Pemanfaatan limbah beton ini sebagai salah satu jawaban terkait kelestarian lingkungan dan sesuai dengan konsep sustainable construction (konstruksi berkelanjutan) dengan visi green building dan green construction.

Salah satu penyebab material beton tidak sempurna adalah segregasi pada tahap pelaksanaan. Guna meminimalisir hal tersebut telah banyak perusahaan kimia dan kalangan akademis melakukan penelitian terkait beton memadat/ mengalir dengan sendirinya, metode ini disebut self compacting concrete (SCC).

Dengan beberapa kasus di atas, maka studi eksperimental ini difokuskan pada pemanfaatan limbah beton sebagai alternatif pengganti agregat kasar alami dan penerapan konsep beton SCC disebut beton SCC-RCA. Hasil studi eksperimental ini akan menentukan apakah beton SCC-RCA dapat digunakan dalam pembuatan beton baru.

\section{Beton Dengan Agregat Daur Ulang}

Pada umumnya recycle coarse aggregtes (RCA) sebagai pengganti agregat alami harus memenuhi syaratsyarat yang serupa dengan agregat alami (NCA), pemanfaatan RCA berpengaruh pada sifat fisik dan mekanikal beton keras. Pemanfaatan RCA sebagai alternatif pengganti agregat kasar memiliki beberapa perubahan sifat fisik dan mekanis di antaranya: kekuatan tekan (berkurang 0 s.d 24\%), kekuatan tarik (berkurang 0 s.d 10\%), dll [1].
Salah satu penelitian terkait pemanfaatan limbah beton sebagai agregat daur ulang (recycled concrete aggregates/ RCA) yang sudah dilakukan dan sebagai bahan pertimbangan yaitu kekuatan tekan menurun sekitar $10 \%$ - $30 \%$, [2]. Limbah beton daur ulang sudah dipabrikasi untuk beberapa kebutuhan terhadap industri konstruksi di antaranya: kerb dan gutter, granular base course, embankment fill, paving blocks, backfill and building blocks [3].

\section{Beton Memadat Sendiri (SCC)}

Beton memadat sendiri (self compacting concrete) adalah beton yang memiliki kemampuan untuk mengalir dan memadat sendiri tanpa menggunakan alat penggetar atau alat pemadat. Beton SCC harus merupakan beton segar dengan karakter mempunyai nilai slump yang tinggi (flowable) tanpa mengalami segregasi dan tidak memerlukan pemadatan mekanik selama proses pengecoran [4]. Beton SCC memiliki sifat yaitu: filling ability (mengalir dan mengisi semua ruang dalam bekisting pengaruh gravitasi) dan passing ability (mengalir melalui celah sempit tanpa hambatan dan segregasi).

Beton dengan konsep SCC memiliki beberapa sifat mekanikal di antaranya: kekuatan tekan, kekuatan lentur dan modulus elastisitas. Sifat mekanikal untuk kekuatan tekan beton yang dihasilkan tidak ada perbedaan yang signifikan antara beton konvensional dan beton dengan konsep SCC [5] sedangkan mekanikal untuk kekuatan lentur beton dengan konsep SCC memiliki nilai kekuatan lentur yang lebih tinggi dibandingkan dengan beton konvesional [6].

Terkait dengan modulus elastisitas beton [7], penelitian tersebut membandingkan nilai modulus elastisitas dengan kekuatan tekan beton yang sama. Penelitian pertama menunjukkan bahwa nilai modulus 
elastisitas beton SCC lebih rendah $10-$ $15 \%$ dari beton konvesional [8]. Penelitian kedua menunjukkan bahwa nilai modulus elastisitas beton SCC sama dengan beton konvesional [9].

\section{Pengujian Kekuatan Tekan Beton}

Tabel 1. Jumlah Benda Uji Silinder Beton

\begin{tabular}{|c|c|c|c|c|c|c|}
\hline \multirow{3}{*}{$\begin{array}{c}\text { Mix } \\
\text { Design }\end{array}$} & \multicolumn{6}{|c|}{ Jumlah Benda Uji } \\
\hline & \multicolumn{5}{|c|}{ Pengujian Hari Ke- (buah) } & \multirow{2}{*}{$\begin{array}{c}\text { Total } \\
\text { (buah) }\end{array}$} \\
\hline & 3 & 7 & 14 & 21 & 28 & \\
\hline $1 \mathrm{~A}$ & 3 & 3 & 3 & 3 & 3 & 15 \\
\hline $2 \mathrm{~A}$ & 3 & 3 & 3 & 3 & 3 & 15 \\
\hline $1 \mathrm{~B}$ & 3 & 3 & 3 & 3 & 3 & 15 \\
\hline $2 B$ & 3 & 3 & 3 & 3 & 3 & 15 \\
\hline \multicolumn{6}{|c|}{ Total } & 60 \\
\hline
\end{tabular}

Prosedur pengujian kekuatan tekan beton berpedoman pada SNI 1974:2011 [10]. Benda uji beton berbentuk silinder dengan diameter $100 \mathrm{~mm}$ dan tinggi $200 \mathrm{~mm}$ [11]. Beton boleh dibuka dari bekisting setelah 24 jam terhitung saat beton berada dalam bekisting. Kemudian dilaksanakan perawatan (curing) beton. Untuk mendapatkan nilai kekuatan tekan beton adalah dengan pemberian beban tekan hingga mencapai beban puncak (ultimate) pada masing-masing benda uji dan pada masing-masing umur beton $(3,7,14$, 21, dan 28 hari). Perhitungan kekuatan tekan beton menggunakan persamaan:

$\mathrm{f}_{\mathrm{C}}=\frac{P u}{A C}$

di mana,

$\mathrm{f}_{\mathrm{c}}$ kekuatan tekan beton (MPa)

$\mathrm{P}_{\mathrm{u}}$ beban ultimate (puncak) beton, dari hasil pengujian $(\mathrm{N})$

$A_{c}$ luas penampang silinder beton $\left(\mathrm{mm}^{2}\right)$
Perhitungan Kekuatan Tekan Karakteristik Beton

Hasil kekuatan tekan beton yang didapat dengan menggunakan persamaan 1 akan dievaluasi untuk mendapatkan kekuatan tekan karakteristik beton [11], yaitu dengan persamaan:

$\mathrm{f}_{\mathrm{c}}{ }^{\prime}=\mathrm{f}_{\mathrm{cr}}{ }^{\prime}-\mathrm{k}^{*} \mathrm{sd}$

$\mathrm{sd}=\sqrt{\frac{\Sigma(f c i 28-f c 28)^{2}}{(n-1)}}$

di mana,

$\mathrm{f}_{\mathrm{c}}$ ' kekuatan tekan karakteristik beton (MPa)

$\mathrm{f}_{\mathrm{cr}}$ ' kekuatan tekan rancangan beton, untuk hasil eksperimental $\mathrm{f}_{\mathrm{c} 28 \mathrm{r}}{ }^{\prime}=\mathrm{f}_{\mathrm{c} 28}$ (MPa)

$\mathrm{k} \quad$ konstanta (nilai $=1.34$, untuk 5\% benda uji diizinkan gagal)

sd standar deviasi

$\mathrm{f}_{\mathrm{ci} 28}$ kekuatan tekan beton hasil eksperimental terhadap faktor umur (MPa).

Untuk kekuatan tekan regresi beton menggunakan persamaan linier:

$\mathrm{f}^{\prime}=\frac{X}{a X+b}$

di mana,

f' kekuatan tekan regresi beton (MPa)

$\mathrm{X}$ umur beton (hari)

a koefisien regresi, dari persamaan regresi beton

b konstanta regresi, dari persamaan regresi beton 


\section{Flow Chart Eksperimental}

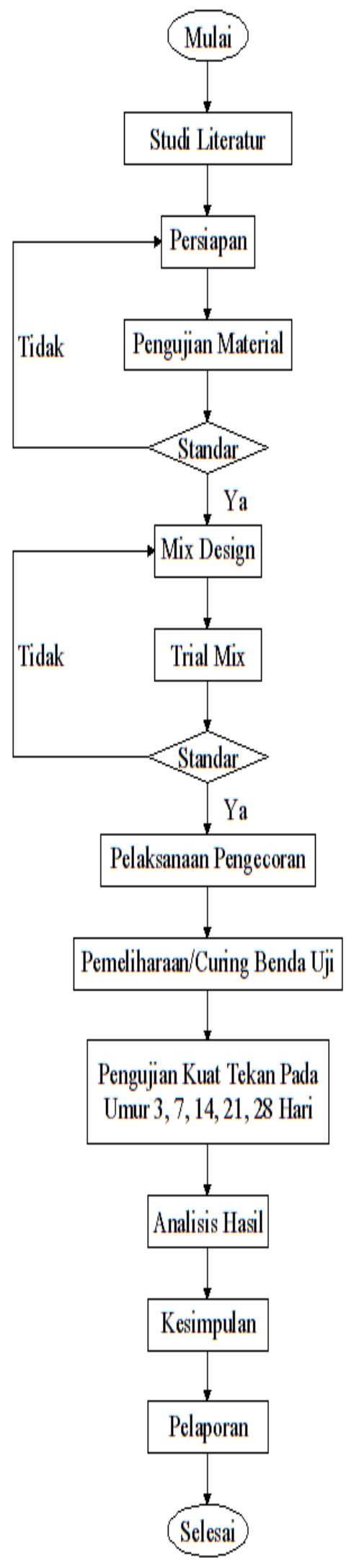

Gambar 1. Flow Chart Eksperimental

\section{METODE PENELITIAN}

\section{Material}

Material yang digunakan dalam penelitian ini adalah sebagai berikut:

1. Semen yang digunakan adalah tipe PCC (Portland Composite Cement) yang diproduksi oleh dari PT Tiga Roda. Semen tipe PCC produk PT Tiga Roda, sudah mengacu pada SNI 7064:2014 [12].

2. Agregat halus yang digunakan adalah agregat halus alami (pasir hitam/ pasir beton), agregat halus alami yang digunakan adalah agregat halus alami yang lolos saringan No. 4 yang berukuran 4.75 $\mathrm{mm}$.

3. Agregat kasar yang digunakan adalah agregat kasar alami (split) dan agregat kasar daur ulang (recycle coarse aggregate), ukuran maksimum agregat kasar yang digunakan adalah $12.50 \mathrm{~mm}$ dan $19.00 \mathrm{~mm}$.

4. Air berasal dari tanah yang tersedia di Laboratorium Teknik Struktur Universitas Katolik Parahyangan.

5. Superplaticizer tipe ViscoCrete 3115N yang diproduksi oleh PT Sika Indonesia.

\section{Propertis Agregat}

Tabel 2. Hasil Pemeriksaan Propertis Agregat

\begin{tabular}{|c|c|c|c|c|c|}
\hline Agg. & $\begin{array}{l}\text { Kd. } \\
\text { Air } \\
(\%)\end{array}$ & FM & $\begin{array}{c}\text { Berat } \\
\text { Isi } \\
\text { Padat } \\
\left(\mathrm{gr} / \mathrm{cm}^{3}\right)\end{array}$ & SG & Absorpsi \\
\hline Pasir & 7.31 & 2.59 & - & 2.53 & 4.01 \\
\hline Split & 2.91 & - & 1.22 & 2.58 & 3.48 \\
\hline RCA & 3.03 & - & 1.19 & 2.54 & 4.96 \\
\hline
\end{tabular}

Spesifikasi dan karkteristik agregat sebagai material penyusun beton dapat diperoleh dengan melakukuan pemeriksaan propertis di laboratorium. Pemeriksaan agregat ini bertujuan untuk 
mendapatkan proporsi campuran beton (mix design) sesuai dengan kekuatan tekan rancangan. Pemeriksaan agregat (Tabel 2) yang dilakukan adalah terhadap agregat halus (pasir) dan agregat kasar alami (split) serta agregat kasar daur ulang (RCA).

\section{Perancangan Campuran Beton}

Perancangan proporsi campuran beton (mix design) dihitung berdasarkan hasil pemeriksaan propertis agregat (Tabel 2). Untuk perancangan proporsi campuran beton menggunakan agregat kasar alami (NCA) berpedoman pada ACI 211.1-91 [13] (Tabel 3).

Tabel 3. Mix Design Agregat Kasar Alami (Split)

\begin{tabular}{cccc} 
Mix Design & Unit & 1A & 2A \\
\hline $\begin{array}{c}\text { fc' Design } \\
\text { Size of } \\
\text { Agg. }\end{array}$ & $(\mathrm{MPa})$ & 28 & 28 \\
Air & $(\mathrm{mm})$ & 12.50 & 19.00 \\
Semen & $(\mathrm{kg})$ & 4.88 & 4.63 \\
Split & $(\mathrm{kg})$ & 18.55 & 20.83 \\
Pasir & $(\mathrm{kg})$ & 26.62 & 26.00 \\
ViscoCrete & $(\%)$ & 2.00 & 2.00 \\
$\mathbf{3 1 1 5 N}$ & $(\mathrm{kg})$ & 0.20 & 0.19 \\
\hline
\end{tabular}

Metode yang sama juga diterapkan pada perancangan proporsi campuran beton (mix design) menggunakan agregat kasar daur ulang (RCA) pada Tabel 4. Proporsi campuran beton pada Tabel 3 dan Tabel 4 diklarifikasi dengan percobaan pelaksanaan proporsi campuran beton (mix design) yang telah dirancang (trial mix).
Tabel 4. Mix Design Agregat Kasar Daur Ulang (RCA)

\begin{tabular}{|c|c|c|c|}
\hline Mix Design & Unit & 1B & 2B \\
\hline$f c^{\prime}$ Design & $(\mathrm{MPa})$ & 28 & 28 \\
\hline $\begin{array}{c}\text { Size of } \\
\text { Agg. }\end{array}$ & $(\mathrm{mm})$ & 12.50 & 19.00 \\
\hline Air & (kg) & 5.11 & 4.89 \\
\hline Semen & (kg) & 9.82 & 9.32 \\
\hline RCA & (kg) & 18.12 & 20.34 \\
\hline Pasir & (kg) & 26.82 & 26.23 \\
\hline \multirow{2}{*}{$\begin{array}{c}\text { Viscocrete } \\
\text { 3115N }\end{array}$} & (\%) & 2.50 & 2.50 \\
\hline & (kg) & 0.25 & 0.23 \\
\hline
\end{tabular}

\section{Slump Flow}

Berdasarkan EFNARC 2002 [14] metode pengujian untuk beton memadat sendiri (self compacting concrete/ SCC) pada eksperimental ini terkait workability dengan menggunakan 2 metode yaitu: Slump-flow by abrams cone (650 s.d $800 \mathrm{~mm}, \pm 50 \mathrm{~mm}$ ) dan $\mathrm{T}_{50} \mathrm{~cm}$ slump-flow (3 s.d 7 detik for civil engineering application dan 2 s.d 5 detik for houshing application), kedua metode ini dapat diterima dengan ukuran agregat maksimum $20 \mathrm{~mm}$.

Tabel 5. Nilai Slump Flow

\begin{tabular}{ccc} 
Mix Design & $\begin{array}{c}\text { Abrams } \\
\text { Cone } \\
\text { (mm) }\end{array}$ & $\begin{array}{c}\mathbf{T}_{\mathbf{5 0}} \mathbf{c m} \\
\text { (detik) }\end{array}$ \\
\hline 1A & 692.50 & 5.10 \\
2A & 607.50 & 5.20 \\
1B & 667.50 & 5.30 \\
2B & 572.50 & 5.60 \\
\hline
\end{tabular}

Terkait dengan kriteria nilai slump flow dapat berpedoman pada EFCA 2005 [15] di mana nilai berkisar 550 s.d > $850 \mathrm{~mm}$. Hasil slump flow pada keempat mix design dapat dilihat pada Tabel 5. 
HASIL DAN PEMBAHASAN Hasil Eksperimental Kekuatan Tekan Beton

Pada eksperimental ini perawatan (curing) beton menggunakan metode self curing dengan menngunakan plastik sebagai pembungkus benda uji beton. Lama perawatan benda uji beton tergantung umur pengujian beton. Setelah benda uji dikeluarkan dari plastik, maka akan dilaksanakan pengukuran di antaranya adalah diameter, tinggi dan berat isi beton. Selanjutnya pelaksanaan capping (pemerataan penampang bagian atas beton) dengan menggunakan belerang, agar beban yang diterima terdistribusi merata ke permukaan beton.

Pelaksanaan pengujian pemberian beban tekan untuk mendapatkan nilai kekuatan tekan beton menggunakan alat compression testing machine (CTM) di
Laboratorium Teknik Struktur Universitas Katolik Parahyangan Bandung. Metode pengujian dengan alat CTM, pembebanan diberikan secara perlahan dengan pace rate (tingkat kecepatan) $2.4 \mathrm{kN} / \mathrm{sec}$ hingga benda uji hancur atau mencapai beban ultimate (puncak). Perhitungan kekuatan tekan beton menggunakan persamaan 1. Pelaksanaan pemberian beban tekan ini dilakukan terhadap semua benda uji (masing-masing mix design). Beban ultimate (puncak) diperoleh selanjutnya akan dihitung nilai kekuatan tekan beton (persamaan 1) berdasarkan masing-masing pengukuran dimensi benda uji, setelah diperolah nilai kekutan tekan beton dihitung nilai rata-rata kekuatan tekan beton berdasarkan umur beton masingmasing mix design 3, 7, 14, 21, dan 28 hari. (Tabel 6, 7, 8, dan Tabel 9).

Tabel 6. Data Hasil Pengujian Kekuatan Tekan Beton 1A

\begin{tabular}{|c|c|c|c|c|c|c|c|}
\hline \multirow{3}{*}{$\begin{array}{c}\text { Benda } \\
\text { Uji }\end{array}$} & \multirow{2}{*}{$\begin{array}{l}\text { Umur } \\
\text { Beton }\end{array}$} & \multicolumn{2}{|c|}{ Dimensi } & \multirow{2}{*}{$\begin{array}{c}\text { Berat } \\
\text { Isi }\end{array}$} & \multirow{2}{*}{$\begin{array}{c}\text { Beban } \\
\text { Ultimate }\end{array}$} & \multirow{2}{*}{$\begin{array}{c}\text { Kekuatan } \\
\text { Tekan }\end{array}$} & \multirow{2}{*}{$\begin{array}{c}\text { Kekuatan } \\
\text { Tekan } \\
\text { Rata-Rata }\end{array}$} \\
\hline & & $\mathbf{D}$ & $\mathbf{H}$ & & & & \\
\hline & X (Hari) & $(\mathrm{mm})$ & $(\mathrm{mm})$ & (gr) & $\mathrm{P}_{\mathrm{u}}(\mathrm{kN})$ & $\mathrm{f}_{\mathrm{c}}(\mathrm{MPa})$ & $\mathrm{f}_{\mathrm{cX}}(\mathrm{MPa})$ \\
\hline $1 \mathrm{~A}-3.1$ & & 97.88 & 202.50 & 3510 & 193.50 & 25.72 & \\
\hline $1 \mathrm{~A}-3.2$ & 3 & 99.53 & 201.50 & 3550 & 184.10 & 23.66 & 24.69 \\
\hline $1 \mathrm{~A}-3.3$ & & 98.31 & 200.50 & 3490 & 187.50 & 24.70 & \\
\hline $1 \mathrm{~A}-7.1$ & & 97.65 & 203.00 & 3510 & 209.50 & 27.97 & \\
\hline $1 \mathrm{~A}-7.2$ & 7 & 100.04 & 200.50 & 3570 & 218.30 & 27.78 & 27.52 \\
\hline $1 \mathrm{~A}-7.3$ & & 100.03 & 201.50 & 3580 & 210.80 & 26.82 & \\
\hline 1A-14.1 & & 100.03 & 199.50 & 3550 & 229.50 & 29.20 & \\
\hline 1A-14.2 & 14 & 98.67 & 203.50 & 3570 & 239.80 & 31.36 & 29.42 \\
\hline 1A-14.3 & & 100.16 & 199.50 & 3540 & 218.20 & 27.70 & \\
\hline 1A-21.1 & & 98.66 & 202.50 & 3520 & 252.11 & 32.98 & \\
\hline 1A-21.2 & 21 & 100.00 & 200.50 & 3560 & 273.00 & 34.76 & 33.05 \\
\hline 1A-21.3 & & 100.01 & 201.00 & 3570 & 246.70 & 31.40 & \\
\hline 1A-28.1 & & 98.57 & 202.50 & 3550 & 257.90 & 33.80 & \\
\hline 1A-28.2 & 28 & 98.33 & 203.50 & 3530 & 263.90 & 34.76 & 34.87 \\
\hline 1A-28.3 & & 97.57 & 204.00 & 3490 & 269.70 & 36.07 & \\
\hline
\end{tabular}


Tabel 7. Data Hasil Pengujian Kekuatan Tekan Beton 1B

\begin{tabular}{|c|c|c|c|c|c|c|c|}
\hline \multirow{3}{*}{$\begin{array}{c}\text { Benda } \\
\text { Uji }\end{array}$} & \multirow{2}{*}{$\begin{array}{l}\text { Umur } \\
\text { Beton }\end{array}$} & \multicolumn{2}{|c|}{ Dimensi } & \multirow{2}{*}{$\begin{array}{c}\text { Berat } \\
\text { Isi }\end{array}$} & \multirow{2}{*}{$\begin{array}{c}\text { Beban } \\
\text { Ultimate }\end{array}$} & \multirow{2}{*}{$\begin{array}{c}\text { Kekuatan } \\
\text { Tekan }\end{array}$} & \multirow{2}{*}{$\begin{array}{c}\text { Kekuatan } \\
\text { Tekan } \\
\text { Rata-Rata }\end{array}$} \\
\hline & & D & $\mathbf{H}$ & & & & \\
\hline & X (Hari) & $(\mathrm{mm})$ & $(\mathrm{mm})$ & (gr) & $\mathrm{P}_{\mathrm{u}}(\mathrm{kN})$ & $\mathrm{f}_{\mathrm{c}}(\mathrm{MPa})$ & $\mathrm{f}_{\mathrm{cX}}(\mathrm{MPa})$ \\
\hline 1B-3.1 & & 100.28 & 200.50 & 3600 & 150.10 & 19.01 & \\
\hline 1B-3.2 & 3 & 100.28 & 194.50 & 3540 & 151.30 & 19.16 & 18.86 \\
\hline 1B-3.3 & & 100.18 & 191.50 & 3510 & 145.10 & 18.41 & \\
\hline 1B-7.1 & & 100.05 & 200.00 & 3570 & 151.40 & 19.26 & \\
\hline 1B-7.2 & 7 & 98.87 & 199.50 & 3590 & 138.50 & 18.04 & 19.13 \\
\hline 1B-7.3 & & 100.30 & 199.50 & 3600 & 158.70 & 20.09 & \\
\hline 1B-14.1 & & 100.13 & 199.50 & 3630 & 195.60 & 24.84 & \\
\hline $1 B-14.2$ & 14 & 98.53 & 199.50 & 3510 & 184.10 & 24.14 & 24.35 \\
\hline $1 B-14.3$ & & 100.27 & 200.00 & 3600 & 189.90 & 24.05 & \\
\hline 1B-21.1 & & 98.85 & 199.00 & 3500 & 236.40 & 30.81 & \\
\hline 1B-21.2 & 21 & 99.60 & 200.00 & 3540 & 224.30 & 28.79 & 29.53 \\
\hline 1B-21.3 & & 100.21 & 199.50 & 3570 & 228.70 & 29.00 & \\
\hline 1B-28.1 & & 99.85 & 200.50 & 3610 & 256.70 & 32.78 & \\
\hline 1B-28.2 & 28 & 98.98 & 199.00 & 3540 & 248.60 & 32.31 & 32.04 \\
\hline 1B-28.3 & & 97.88 & 199.50 & 3580 & 233.40 & 31.02 & \\
\hline
\end{tabular}

Tabel 8. Data Hasil Pengujian Kekuatan Tekan Beton 2A

\begin{tabular}{|c|c|c|c|c|c|c|c|}
\hline \multirow{3}{*}{$\begin{array}{c}\text { Benda } \\
\text { Uji }\end{array}$} & \multirow{2}{*}{$\begin{array}{l}\text { Umur } \\
\text { Beton }\end{array}$} & \multicolumn{2}{|c|}{ Dimensi } & \multirow{2}{*}{$\begin{array}{c}\text { Berat } \\
\text { Isi }\end{array}$} & \multirow{2}{*}{$\begin{array}{c}\text { Beban } \\
\text { Ultimate }\end{array}$} & \multirow{2}{*}{$\begin{array}{c}\text { Kekuatan } \\
\text { Tekan }\end{array}$} & \multirow{2}{*}{$\begin{array}{c}\text { Kekuatan } \\
\text { Tekan } \\
\text { Rata-Rata }\end{array}$} \\
\hline & & D & $\mathbf{H}$ & & & & \\
\hline & X (Hari) & (mm) & (mm) & (gr) & $\mathrm{P}_{\mathrm{u}}(\mathrm{kN})$ & $\mathrm{f}_{\mathrm{c}}(\mathrm{MPa})$ & $\mathrm{f}_{\mathrm{CX}}(\mathrm{MPa})$ \\
\hline 2A-3.1 & & 100.00 & 200.50 & 3590 & 141.90 & 18.07 & \\
\hline $2 \mathrm{~A}-3.2$ & 3 & 99.63 & 201.50 & 3590 & 153.80 & 19.73 & 19.19 \\
\hline 2A-3.3 & & 99.88 & 202.00 & 3620 & 154.80 & 19.76 & \\
\hline 2A-7.1 & & 100.00 & 202.50 & 3650 & 184.10 & 23.44 & \\
\hline $2 \mathrm{~A}-7.2$ & 7 & 100.01 & 200.50 & 3590 & 190.80 & 24.29 & 24.41 \\
\hline $2 \mathrm{~A}-7.3$ & & 98.82 & 203.50 & 3600 & 195.50 & 25.49 & \\
\hline 2A-14.1 & & 100.23 & 201.00 & 3650 & 220.40 & 27.93 & \\
\hline 2A-14.2 & 14 & 100.18 & 200.50 & 3670 & 208.80 & 26.49 & 27.21 \\
\hline 2A-14.3 & & 100.10 & 199.50 & 3620 & 214.20 & 27.22 & \\
\hline 2A-21.1 & & 99.90 & 200.50 & 3600 & 259.50 & 33.11 & \\
\hline $2 \mathrm{~A}-21.2$ & 21 & 99.87 & 200.50 & 3590 & 262.10 & 33.46 & 33.48 \\
\hline 2A-21.3 & & 99.87 & 201.00 & 3630 & 265.20 & 33.85 & \\
\hline 2A-28.1 & & 98.63 & 201.50 & 3650 & 244.30 & 31.98 & \\
\hline 2A-28.2 & 28 & 99.57 & 200.00 & 3550 & 275.00 & 35.32 & 35.38 \\
\hline $2 \mathrm{~A}-28.3$ & & 97.52 & 199.50 & 3510 & 264.70 & 35.44 & \\
\hline
\end{tabular}


Tabel 9. Data Hasil Pengujian Kekuatan Tekan Beton 2B

\begin{tabular}{|c|c|c|c|c|c|c|c|}
\hline \multirow{3}{*}{$\begin{array}{c}\text { Benda } \\
\text { Uji }\end{array}$} & \multirow{2}{*}{$\begin{array}{l}\text { Umur } \\
\text { Beton }\end{array}$} & \multicolumn{2}{|c|}{ Dimensi } & \multirow{2}{*}{$\begin{array}{l}\text { Berat } \\
\text { Isi }\end{array}$} & \multirow{2}{*}{$\begin{array}{c}\text { Beban } \\
\text { Ultimate }\end{array}$} & \multirow{2}{*}{$\begin{array}{c}\text { Kekuatan } \\
\text { Tekan }\end{array}$} & \multirow{2}{*}{$\begin{array}{c}\text { Kekuatan } \\
\text { Tekan } \\
\text { Rata-Rata }\end{array}$} \\
\hline & & D & $\mathbf{H}$ & & & & \\
\hline & X (Hari) & $(\mathrm{mm})$ & $(\mathrm{mm})$ & (gr) & $\mathrm{P}_{\mathrm{u}}(\mathrm{kN})$ & $\mathrm{f}_{\mathrm{c}}(\mathrm{MPa})$ & $\mathrm{f}_{\mathrm{CX}}(\mathrm{MPa})$ \\
\hline 2B-3.1 & & 99.82 & 201.00 & 3630 & 149.90 & 19.15 & \\
\hline 2B-3.2 & 3 & 99.76 & 200.50 & 3590 & 142.00 & 18.17 & 18.06 \\
\hline 2B-3.3 & & 99.88 & 200.50 & 3590 & 132.00 & 16.85 & \\
\hline 2B-7.1 & & 97.59 & 204.50 & 3540 & 159.90 & 21.38 & \\
\hline $2 B-7.2$ & 7 & 100.14 & 201.50 & 3690 & 186.80 & 23.72 & 22.49 \\
\hline 2B-7.3 & & 100.09 & 201.50 & 3640 & 175.90 & 22.36 & \\
\hline 2B-14.1 & & 100.23 & 201.00 & 3650 & 193.40 & 24.51 & \\
\hline 2B-14.2 & 14 & 100.18 & 200.50 & 3670 & 211.10 & 26.78 & 25.22 \\
\hline 2B-14.3 & & 99.87 & 199.50 & 3620 & 190.90 & 24.37 & \\
\hline 2B-21.1 & & 100.06 & 201.50 & 3640 & 227.30 & 28.91 & \\
\hline 2B-21.2 & 21 & 99.91 & 200.50 & 3640 & 226.50 & 28.89 & 28.84 \\
\hline 2B-21.3 & & 100.09 & 201.50 & 3670 & 226.00 & 28.72 & \\
\hline 2B-28.1 & & 99.98 & 199.50 & 3580 & 249.20 & 31.74 & \\
\hline 2B-28.2 & 28 & 100.18 & 202.50 & 3650 & 249.70 & 31.68 & 31.73 \\
\hline 2B-28.3 & & 98.89 & 200.00 & 3600 & 244.00 & 31.77 & \\
\hline
\end{tabular}

\section{Analisis Kekuatan Tekan Regresi Beton}

Data kekuatan tekan rata-rata $\left(\mathrm{f}_{\mathrm{cX}}\right)$ masing-masing mix design pada hari ke 3, 7, 14, 21 dan 28 hasil eksperimental (Tabel 6, 7, 8 dan Tabel 9) kemudian dihitung menggunakan persamaan regresi linier (4) sehingga diperoleh persamaan 5, 6, 7 dan persamaan 8 (Gambar 2) dengan koefisien dan konstanta regresi yang berbeda.

Dari persamaan tersebut didapatkan kekuatan tekan regresi beton (f'), faktor umur beton (AF), kekuatan tekan beton pada umur 28 hari $\left(\mathrm{f}_{\mathrm{c} 28}\right)$, standar deviasi (sd) dan untuk menghitung nilai kekuatan tekan karakteristik beton $\left(\mathrm{f}_{\mathrm{c}}{ }^{\prime}\right)$ menggunakan persamaan 2 dapat dilihat pada Tabel 10, 11, 12 dan Tabel 13). Untuk benda uji dengan kode 1B-7.2 (Tabel 11) dan 2A-28.1 (Tabel 12) tidak dimasukkan pada analisis kekuatan tekan regresi beton karena nilai kekuatan tekan yang diperoleh sangat jauh berbeda dengan nilai kekuatan tekan lainnya perbandingan tersebut pada hari yang sama (outlier data).

$$
\begin{aligned}
& \mathrm{f}_{1 \mathrm{~A}}^{\prime}=\frac{X}{0.0267 X+0.0713} \\
& \mathrm{f}^{\prime}{ }_{1 \mathrm{~B}}=\frac{X}{0.0269 X+0.1505} \\
& \mathrm{f}^{\prime}{ }_{2 \mathrm{~A}}=\frac{X}{0.025 X+0.1107} \\
& \mathrm{f}^{\prime}{ }_{2 \mathrm{~B}}=\frac{X}{0.0287 X+0.1096}
\end{aligned}
$$


Tabel 10. Kekuatan Tekan Karakteristik Beton 1A

\begin{tabular}{|c|c|c|c|c|c|c|c|}
\hline \multirow{2}{*}{ No } & \multirow{2}{*}{ Benda Uji } & $\mathbf{X}$ & $\mathbf{f}_{\mathbf{c i}}$ & $\mathbf{f}_{\mathrm{cX}}$ & $\begin{array}{c}\text { f'x }^{\prime} \\
\text { (Pers. 5) }\end{array}$ & $\frac{\text { AF }}{\left(\mathbf{f}^{\prime}{ }_{x} / \mathbf{f}^{\prime}{ }_{28}\right)}$ & $\begin{array}{c}\mathbf{f}_{\mathrm{ci} 28} \\
\left(\mathbf{f}_{\mathrm{c} i} / \mathbf{A F}\right)\end{array}$ \\
\hline & & (Hari) & (MPa) & (MPa) & (MPa) & & (MPa) \\
\hline 1 & $1 \mathrm{~A}-3.1$ & & 25.72 & & & & 39.15 \\
\hline 2 & 1A-3.2 & 4 & 23.66 & 24.69 & 22.46 & 0.66 & 36.02 \\
\hline 3 & 1A-3.3 & & 24.70 & & & & 37.61 \\
\hline 4 & $1 \mathrm{~A}-7.1$ & & 27.97 & & & & 35.28 \\
\hline 5 & $1 \mathrm{~A}-7.2$ & 7 & 27.78 & 27.52 & 27.11 & 0.79 & 35.03 \\
\hline 6 & $1 \mathrm{~A}-7.3$ & & 26.82 & & & & 33.83 \\
\hline 7 & 1A-14.1 & & 29.20 & & & & 31.75 \\
\hline 8 & $1 \mathrm{~A}-14.2$ & 14 & 31.36 & 29.42 & 31.45 & 0.92 & 34.09 \\
\hline 9 & $1 \mathrm{~A}-14.3$ & & 27.70 & & & & 30.11 \\
\hline 10 & 1A-21.1 & & 32.98 & & & & 33.93 \\
\hline 11 & 1A-21.2 & 21 & 34.76 & 33.05 & 33.23 & 0.97 & 35.77 \\
\hline 12 & 1A-21.3 & & 31.40 & & & & 32.32 \\
\hline 13 & 1A-28.1 & & 33.80 & & & & 33.80 \\
\hline 14 & 1A-28.2 & 28 & 34.76 & 34.87 & 34.19 & 1.00 & 34.76 \\
\hline 15 & 1A-28.3 & & 36.07 & & & & 36.07 \\
\hline \multicolumn{4}{|c|}{$\mathbf{f}_{\mathrm{c} 28}$ Rata-Rata } & & & $(\mathrm{MPa})$ & 34.63 \\
\hline \multicolumn{4}{|c|}{ Strandar Deviasi (sd) } & & & & 2.26 \\
\hline \multicolumn{6}{|c|}{ Kekuatan Tekan Karakteristik Beton $\left(\mathrm{f}_{\mathrm{c}}{ }^{\prime}\right)$} & $(\mathrm{MPa})$ & 30.93 \\
\hline
\end{tabular}

Tabel 11. Kekuatan Tekan Karakteristik Beton 1B

\begin{tabular}{|c|c|c|c|c|c|c|c|}
\hline \multirow[t]{2}{*}{ No } & \multirow[t]{2}{*}{ Benda Uji } & $\mathbf{X}$ & $\mathbf{f}_{\mathrm{ci}}$ & $\mathbf{f}_{\mathrm{cX}}$ & \multirow{2}{*}{$\begin{array}{c}\mathbf{f}^{\prime} \mathbf{x} \\
\text { (Pers. 6) } \\
(\mathrm{MPa}) \\
\end{array}$} & \multirow[t]{2}{*}{$\begin{array}{c}\text { AF } \\
\left(\mathbf{f}^{\prime}{ } / \mathbf{f}^{\prime}{ }_{28}\right) \\
\end{array}$} & \multirow{2}{*}{$\begin{array}{c}\frac{\mathbf{f}_{\mathrm{c} i 28}}{\left(\mathbf{f}_{\mathrm{c}} / \mathbf{A F}\right)} \\
(\mathrm{MPa})\end{array}$} \\
\hline & & (Hari) & (MPa) & (MPa) & & & \\
\hline 1 & 1B-3.1 & \multirow{3}{*}{4} & 19.01 & \multirow{3}{*}{18.86} & \multirow{3}{*}{15.50} & \multirow{3}{*}{0.50} & 38.00 \\
\hline 2 & 1B-3.2 & & 19.16 & & & & 38.30 \\
\hline 3 & 1B-3.3 & & 18.41 & & & & 36.81 \\
\hline 4 & 1B-7.1 & \multirow{2}{*}{7} & 19.26 & \multirow{2}{*}{19.67} & \multirow{2}{*}{20.66} & \multirow{2}{*}{0.67} & 28.88 \\
\hline 5 & 1B-7.3 & & 20.09 & & & & 30.12 \\
\hline 6 & 1B-14.1 & \multirow{3}{*}{14} & 24.84 & \multirow{3}{*}{24.35} & \multirow{3}{*}{26.56} & \multirow{3}{*}{0.86} & 28.98 \\
\hline 7 & 1B-14.2 & & 24.14 & & & & 28.17 \\
\hline 8 & 1B-14.3 & & 24.05 & & & & 28.06 \\
\hline 9 & 1B-21.1 & \multirow{3}{*}{21} & 30.81 & \multirow{3}{*}{28.90} & \multirow{3}{*}{29.35} & \multirow{4}{*}{0.95} & 32.52 \\
\hline 10 & 1B-21.2 & & 28.79 & & & & 30.39 \\
\hline 11 & 1B-21.3 & & 29.00 & & & & 30.61 \\
\hline 12 & 1B-28.1 & \multirow{3}{*}{28} & 32.78 & \multirow{3}{*}{32.04} & \multirow{3}{*}{30.98} & & 32.78 \\
\hline 13 & 1B-28.2 & & 32.31 & & & \multirow[t]{2}{*}{1.00} & 32.31 \\
\hline 14 & 1B-28.3 & & 31.02 & & & & 31.02 \\
\hline \multicolumn{6}{|c|}{$\mathbf{f}_{\mathrm{c} 28}$ Rata-Rata } & $(\mathrm{MPa})$ & 31.92 \\
\hline \multicolumn{6}{|c|}{ Strandar Deviasi (sd) } & & 3.48 \\
\hline \multicolumn{6}{|c|}{ Kekuatan Tekan Karakteristik Beton $\left(\mathbf{f}_{\mathrm{c}}{ }^{\prime}\right)$} & $(\mathrm{MPa})$ & 26.21 \\
\hline
\end{tabular}


Tabel 12. Kekuatan Tekan Karakteristik Beton 2A

\begin{tabular}{|c|c|c|c|c|c|c|c|}
\hline \multirow[t]{2}{*}{ No } & \multirow[t]{2}{*}{ Benda Uji } & $\mathbf{X}$ & $\mathbf{f}_{\mathrm{ci}}$ & $\mathbf{f}_{\mathrm{cX}}$ & $\begin{array}{c}\mathbf{f}^{\prime} \mathrm{x} \\
\text { (Pers. 7) } \\
\end{array}$ & $\begin{array}{c}\text { AF } \\
\left(f^{\prime}{ }_{x} / f^{\prime}{ }_{28}\right) \\
\end{array}$ & $\begin{array}{c}\mathbf{f}_{\mathrm{c} i 28} \\
\left(\mathbf{f}_{\mathrm{c} i} / \mathbf{A F}\right) \\
\end{array}$ \\
\hline & & (Hari) & (MPa) & (MPa) & (MPa) & & (MPa) \\
\hline 1 & 2A-3.1 & \multirow{3}{*}{3} & 18.07 & \multirow{3}{*}{19.19} & \multirow{3}{*}{0.16} & \multirow{3}{*}{16.16} & 38.63 \\
\hline 2 & $2 A-3.2$ & & 19.73 & & & & 42.18 \\
\hline 3 & $2 \mathrm{~A}-3.2$ & & 19.76 & & & & 42.24 \\
\hline 4 & 2A-7.1 & \multirow{3}{*}{7} & 23.44 & \multirow{3}{*}{24.41} & \multirow{3}{*}{0.29} & \multirow{3}{*}{24.50} & 33.04 \\
\hline 5 & $2 \mathrm{~A}-7.2$ & & 24.29 & & & & 34.24 \\
\hline 6 & $2 \mathrm{~A}-7.3$ & & 25.49 & & & & 35.93 \\
\hline 7 & 2A-14.1 & \multirow{3}{*}{14} & 27.93 & \multirow{3}{*}{27.21} & \multirow{3}{*}{0.51} & \multirow{3}{*}{30.39} & 31.75 \\
\hline 8 & 2A-14.2 & & 26.49 & & & & 30.11 \\
\hline 9 & $2 \mathrm{~A}-4.2$ & & 27.22 & & & & 30.94 \\
\hline 10 & 2A-21.1 & \multirow{3}{*}{21} & 33.11 & \multirow{3}{*}{33.48} & \multirow{3}{*}{0.63} & \multirow{3}{*}{33.03} & 34.62 \\
\hline 11 & $2 \mathrm{~A}-21.2$ & & 33.46 & & & & 34.98 \\
\hline 12 & $2 \mathrm{~A}-21.2$ & & 33.85 & & & & 35.40 \\
\hline 13 & 2A-28.2 & \multirow{2}{*}{28} & 35.32 & \multirow{2}{*}{35.38} & \multirow{2}{*}{0.79} & \multirow{2}{*}{34.54} & 35.32 \\
\hline 14 & 2A-28.3 & & 35.44 & & & & 35.44 \\
\hline \multicolumn{6}{|c|}{$\mathbf{f}_{\mathrm{c} 28}$ Rata-Rata } & (MPa) & 35.34 \\
\hline \multicolumn{6}{|c|}{ Strandar Deviasi (sd) } & & 3.64 \\
\hline \multicolumn{6}{|c|}{ Kekuatan Tekan Karakteristik Beton $\left(\mathbf{f}_{\mathrm{c}}{ }^{\prime}\right)$} & $(\mathrm{MPa})$ & 29.37 \\
\hline
\end{tabular}

Tabel 13. Kekuatan Tekan Karakteristik Beton 2B

\begin{tabular}{|c|c|c|c|c|c|c|c|}
\hline \multirow[t]{2}{*}{ No } & \multirow[t]{2}{*}{ Benda Uji } & $\mathbf{X}$ & $\mathbf{f}_{\mathrm{ci}}$ & $\mathbf{f}_{\mathrm{cX}}$ & $\begin{array}{c}\mathbf{f}^{\prime} x \\
\text { (Pers. 8) }\end{array}$ & $\frac{\mathbf{A F}}{\left(\mathbf{f}^{\prime}{ }_{\mathrm{X}} / \mathbf{f}^{\prime}{ }_{28}\right)}$ & $\frac{\mathbf{f}_{\mathrm{c} 28}}{\left(\mathbf{f}_{\mathrm{c}} / \mathrm{AF}\right)}$ \\
\hline & & (Hari) & (MPa) & $(\mathrm{MPa})$ & (MPa) & & (MPa) \\
\hline 1 & 2B-3.1 & & 19.15 & & & & 38.31 \\
\hline 2 & 2B-3.2 & 3 & 18.17 & 18.06 & 15.33 & 0.50 & 36.34 \\
\hline 3 & 2B-3.3 & & 16.85 & & & & 33.70 \\
\hline 4 & 2B-7.1 & & 21.38 & & & & 29.08 \\
\hline 5 & 2B-7.2 & 7 & 23.72 & 22.49 & 22.54 & 0.74 & 32.26 \\
\hline 6 & 2B-7.3 & & 22.36 & & & & 30.41 \\
\hline 7 & 2B-14.1 & & 26.78 & & & & 27.45 \\
\hline 8 & 2B-14.2 & 14 & 24.37 & 25.22 & 27.38 & 0.89 & 30.00 \\
\hline 9 & 2B-14.3 & & 28.91 & & & & 27.30 \\
\hline 10 & 2B-21.1 & & 28.89 & & & & 30.07 \\
\hline 11 & 2B-21.2 & 21 & 28.72 & 28.84 & 29.48 & 0.96 & 30.05 \\
\hline 12 & 2B-21.3 & & 31.74 & & & & 29.87 \\
\hline 13 & 2B-28.1 & & 31.68 & & & & 31.74 \\
\hline 14 & 2B-28.2 & 28 & 31.77 & 31.73 & 30.66 & 1.00 & 31.68 \\
\hline 15 & 2B-28.3 & & 0.00 & & & & 31.77 \\
\hline \multicolumn{4}{|c|}{$\mathbf{f}_{\mathrm{c} 28}$ Rata-Rata } & & & (MPa) & 31.33 \\
\hline \multicolumn{4}{|c|}{ Strandar Deviasi (sd) } & & & & 2.99 \\
\hline \multicolumn{4}{|c|}{ Kekuatan Tekan Karakteristik Beton $\left(f_{c}{ }^{\prime}\right)$} & & & (MPa) & 26.43 \\
\hline
\end{tabular}




\section{Perkembangan Kekuatan Tekan Beton}

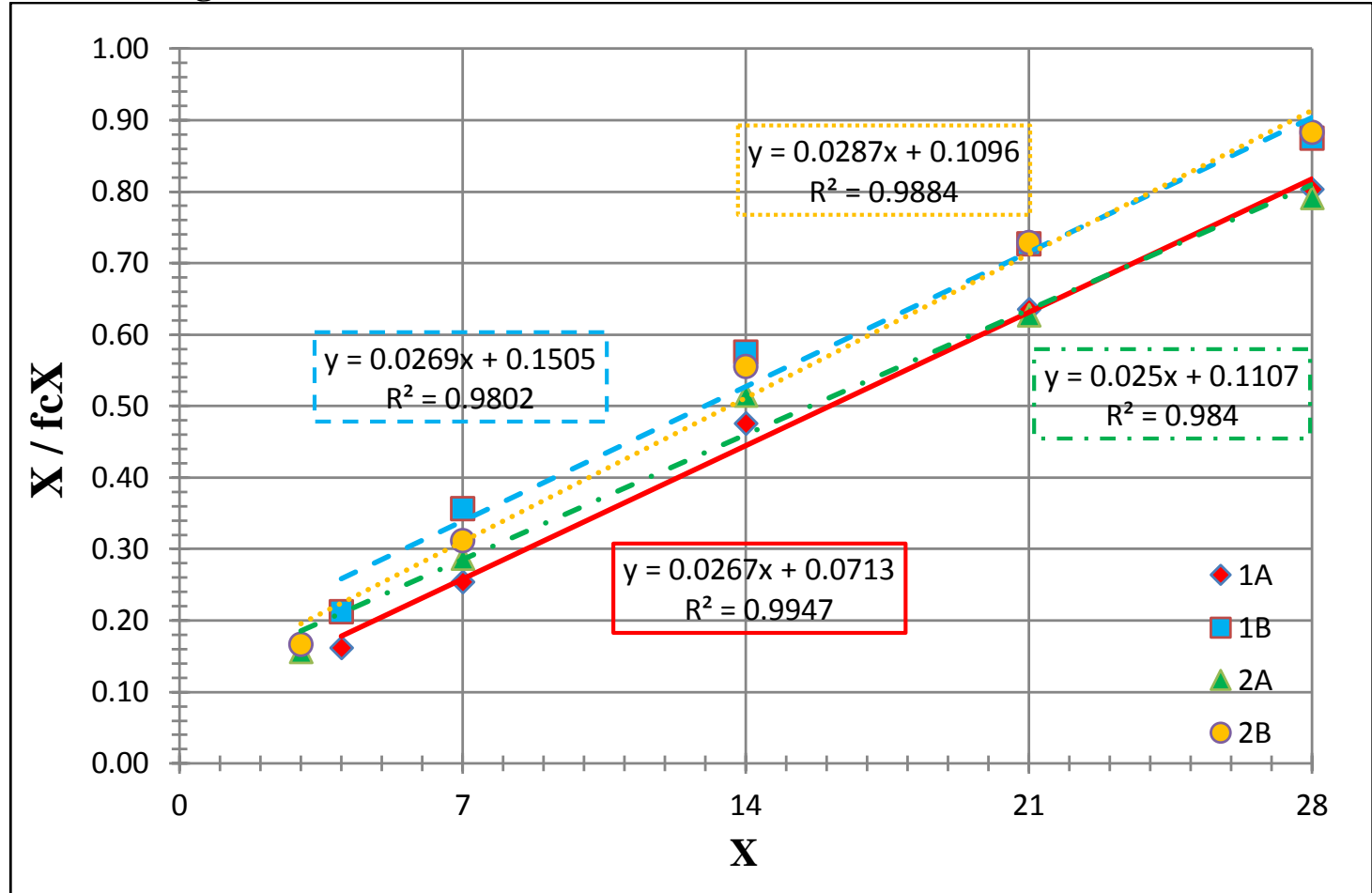

Gambar 2. Persamaan Kekuatan Tekan Regresi Beton Pada Masing-Masing Mix Design

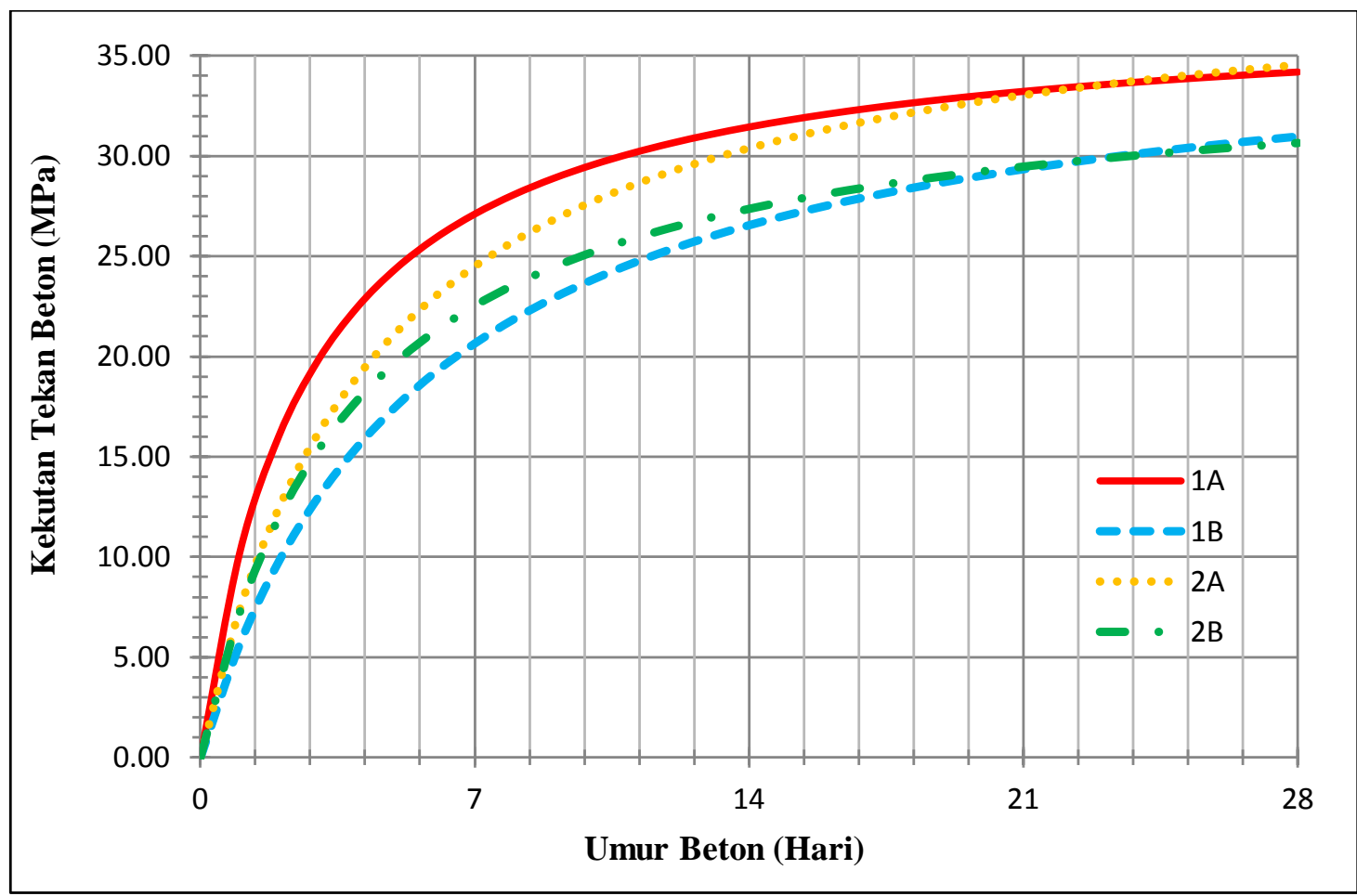

Gambar 3. Grafik Perbandingan Kekuatan Tekan Terhadap Umur Beton Pada Masing-Masing Mix Design 
Dari persamaan regresi beton (persamaan 5, 6, 7 dan persamaan 8) diperoleh perkembangan kekuatan tekan beton pada setiap hari (awal hingga 28 hari) umur beton (Gambar 3). Dari gambar 3 jika ditinjau dari perkembangan umur beton dapat terlihat bahwa pada umur beton 3 hingga 14 hari terlihat perbedaan di mana kekuatan tekan beton secara berurut dari yang paling tinggi adalah 1A, 2A, 2B dan 1B, sedangkan pada umur beton 21 hingga 28 hari terlihat perbedaan signifikan antara $1 \mathrm{~A}$ dan $2 \mathrm{~A}$ (SCC-NCA) terhadap 1B dan 2B (SCCRCA). Untuk perbandingan hasil kekuatan tekan beton antara beton dengan konsep SCC menggunakan agregat kasar alami (natural coarse aggregates) terhadap beton dengan konsep SCC menggunakan agregat kasar daur ulang (recycle coarse aggregates) terlihat perbedaan yang signifikan.

\section{Perbandingan Kekuatan Tekan Beton Hasil Eksperimental Terhadap Rancangan}

Tabel 14. Perbandingan Kekuatan Tekan Beton Hasil Eksperimental Terhadap Kekuatan Tekan Beton Rancangan

\section{Kekuatan Tekan Rata-Rata 28 Hari Kekuatan Tekan Karakteristik}

\begin{tabular}{|c|c|c|c|c|c|c|c|}
\hline \multirow{3}{*}{$\begin{array}{c}\text { Mix } \\
\text { Design } \\
\text { (ij) }\end{array}$} & \multirow[t]{2}{*}{$\begin{array}{c}\text { Size of } \\
\text { Agg. }\end{array}$} & Design & $\begin{array}{c}\text { Hasil } \\
\text { Eksperimen }\end{array}$ & $\begin{array}{c}\text { Rasio } \\
\text { (NCA/RCA) }\end{array}$ & Design & $\begin{array}{c}\text { Hasil } \\
\text { Eksperimen }\end{array}$ & $\begin{array}{c}\text { Rasio } \\
\text { (NCA/RCA) }\end{array}$ \\
\hline & & $\left(\mathbf{f}_{\mathrm{cr}}\right)$ & $\left(\mathbf{f}_{\mathrm{cij}}\right)$ & \multirow{2}{*}{$\left(\mathbf{f}_{\mathrm{cijj}} / \mathbf{f}_{\mathrm{ijR}}\right)$} & $\left(\mathbf{f}_{\mathrm{cr}}{ }^{\prime}\right)$ & $\left(\mathbf{f}_{\mathrm{cij}}{ }^{\prime}\right)$ & \multirow{2}{*}{$\left(\mathbf{f}_{\mathrm{cijN}}{ }^{\prime} / \mathbf{f}_{\mathrm{ijR}}{ }^{\prime}\right)$} \\
\hline & $(\mathrm{mm})$ & (MPa) & (MPa) & & (MPa) & (MPa) & \\
\hline $1 \mathrm{~A}$ & \multirow{2}{*}{12.50} & \multirow{3}{*}{28.00} & 34.87 & \multirow{2}{*}{1.09} & \multirow{3}{*}{20.00} & 30.93 & \multirow{2}{*}{1.18} \\
\hline 1B & & & 32.04 & & & 26.21 & \\
\hline $\begin{array}{l}2 \mathrm{~A} \\
2 \mathrm{~B}\end{array}$ & 19.00 & & 35.38 & 1.11 & & 29.37 & 1.11 \\
\hline
\end{tabular}

Berdasarkan Tabel 14, jika ditinjau pada hasil kekuatan tekan rata-rata 28 hari $\left(\mathrm{f}_{\mathrm{cij}}\right)$ hasil eksperimental (Gambar 4) pada mix design 1B (SCC-RCA) mengalami penurunan $2.84 \mathrm{MPa}$ (sekitar 8\%) terhadap mix design 1A (SCC-NCA) dengan rasio perbandingan $\left(\mathrm{f}_{\mathrm{c} 1 \mathrm{~A}} / \mathrm{f}_{\mathrm{c} 1 \mathrm{~B}}\right)$ sebesar 1.09 dan pada mix design 2B (SCC-RCA) juga mengalami penurunan $3.65 \mathrm{MPa}$ (sekitar 10\%) terhadap mix design 2A (SCC-NCA) dengan rasio perbandingan $\left(\mathrm{f}_{\mathrm{c} 2 \mathrm{~A}} / \mathrm{f}_{\mathrm{c} 2 \mathrm{~B}}\right)$ sebesar 1.11.

Hal yang sama terjadi pada kekuatan tekan karakteristik beton $\left(\mathrm{f}_{\mathrm{cij}}{ }^{\prime}\right)$ hasil eksperimental (Gambar 5) pada mix design 1B (SCC-RCA) mengalami penurunan 4.72 $\mathrm{MPa}$ (sekitar 15\%) terhadap mix design 1A (SCC-NCA) dengan rasio perbandingan $\left(\mathrm{f}_{\mathrm{c} 1 \mathrm{~A}}{ }^{\prime} / \mathrm{f}_{\mathrm{c} 1 \mathrm{~B}}\right.$ ') sebesar 1.18 dan pada mix design 2B (SCC-RCA) juga mengalami penurunan $3.22 \mathrm{MPa}$ (sekitar 10\%) terhadap mix design 2A (SCC-NCA) dengan rasio perbandingan $\left(\mathrm{f}_{\mathrm{c} 2 \mathrm{~A}}\right.$ '/ $/ \mathrm{f}_{\mathrm{c} 2 \mathrm{~B}}$ ') sebesar 1.11 . Dengan hasil perbandingan di atas maka dapat dinyatakan bahwa beton dengan konsep self compacting SCC menggunakan agregat kasar daur ulang (RCA) dapat digunakan sebagai alternatif pengganti beton dengan konsep SCC menggunakan agregat 
kasar alami (NCA) dalam pembuatan beton.

\section{KESIMPULAN}

Dari hasil eksperimental ini dapat diambil beberapa kesimpulan:

1. Penggunaan bahan tambah ViscoCrete $3115 \mathrm{~N}$ disesuaikan dengan material penyusun beton lainnya, pada agregat kasar alami (mix design 1A dan 2A) digunakan 2\% sedangkan pada agregat kasar daur ulang (mix design 1B dan 2B) digunakan 2.5\%. Hasil slump flow memenuhi kriteria beton dengan konsep SCC pada keempat mix design.

2. Kekuatan tekan beton rata-rata umur 28 hari pada mix design 1B (SCCRCA) mengalami penurunan sebesar 2.84 MPa (sekitar 8\%) terhadap mix design 1A (SCCNCA) dengan rasio 1.09 dan pada mix design 2B (SCC-RCA) mengalami penurunan $3.65 \mathrm{MPa}$ (sekitar 10\%) terhadap mix design 2A (SCC-NCA) dengan rasio 1.11.

3. Kekuatan tekan karakteristik beton pada mix design 1B (SCC-RCA) mengalami penurunan sebesar 4.72 MPa (sekitar 15\%) terhadap mix design 1A (SCC-NCA) dengan rasio 1.18 dan pada mix design 2B (SCCRCA) mengalami penurunan 3.22 MPa (sekitar 10\%) terhadap mix design 2A (SCC-NCA) dengan rasio 1.11.

4. Penerapan mix design untuk beton normal menggunakan metode ACI 211.1-91 dapat menjadi beton dengan konsep self compacting (SCC) dengan menggunakan bahan tambah superplasticizer ViscoCrete $3115 \mathrm{~N}$ pada beton menggunakan agregat kasar alami (NCA) dan beton menggunakan agregat kasar daur ulang (RCA).

5. Kekuatan tekan beton rata-rata umur 28 hari dan kekuatan tekan karakteristik beton pada beton dengan konsep self compacting (SCC) dan pemanfaatan limbah beton daur ulang (RCA) sebagai alternatif pengganti agregat kasar alami (NCA) terpenuhi.

\section{UCAPAN TERIMA KASIH}

Penulis mengucapkan terima kasih kepada Bapak Ravin Gunawan selaku National Sales Manager Building System PT Sika Indonesia yang telah memberikan bantuan material superplasticizer SikaViscoCrete 3115N.

\section{DAFTAR PUSTAKA}

[1] American Concrete Pavement Association: ACPA EB043P. (2009). Recycling Concrete Pavements. Engineering Bulettin of American Concrete Pavement Association. Michigan. United States.

[2] El-Reddy, Mohamed Abdallah. (2009). Advanced Materials and Techniques for Reinforced Concrete Structures. CRC Press. Florida. United States.

[3] Nelson, S.C.N. (2004). HighStrength Structural Concrete with Recycled Aggregates. Thesis, University of Southern Queensland. Queensland. Australia.

[4] Kementrian Pekerjaan Umum dan perumahan Rakyat Direktorat Jendral Bina Marga: Spesifikasi Khusus- Interim Skh-1.7.23 dan Skh-1.10.14. (2017). Beton Memadat Sendiri (Sefl Compacting Concrete). Direktorat Jendral Bina Marga. Jakarta. Indonesia.

[5] Zhu,W., John C. Gibss dan P. J. M. Bartos (2001). Uniformity of InSitu-Properties of Self-Compacting Concrete in Full Scale Structural Elements. Jurnal of Cement and 
Concrete Composites Volume 23 Nomor 1, American Concrete Institute. Michigan. United States.

[6] Sonebi, M. dan P. J. M. Bartos (2001). Performance of Reinforced Columns Cast with Self Compacting Concrete. 5th CANMET/ACI International Conference on Recent Advances in Concrete Technology Volume 17, American Concrete Institute. Michigan. United States.

[7] American Concrete Institute: ACI 237R-07. (2007). SelfConsolidating Concrete. American Concrete Institute. Michigan. United States.

[8] Bennenk, W. (2002). SCC in the Daily Precast Concrete Practice. Betonwerk and Fertigteiltechnik. ACI 237R-07. Michigan. United States.

[9] Persson, B. (1999). Creep, Shrinkage and Elastic Modulus of Self-Compacting Concrete. RILEM Proceedings. ACI 237R-07. Michigan. United States.

[10] Badan Stadarisasi Nasional: SNI 1974:2011. (2011). Cara Uji Kuat Tekan Beton Dengan Benda Uji Silinder. Badan Standarisasi Nasional. Jakarta. Indonesia.

[11] Badan Stadarisasi Nasional: SNI 2847:2013. (2013). Persyaratan
Beton Struktural untuk Bangunan Gedung. Badan Standarisasi Nasional. Jakarta. Indonesia.

[12] Badan Stadarisasi Nasional: SNI 7064:2014. (2014). Semen Portland Komposit. Badan Standarisasi Nasional. Jakarta. Indonesia.

[13] American Concrete Institute: ACI 211.1-91. (1991). Standard Practice for Selecting Proportions for Normal, Heavyweight and Mass Concrete. American Concrete Institute. Michigan. United States.

[14] The European Federation of Specialist Construction Chemicals and Concrete Systems: EFNARC 2002. (2002). Spesification and Guidelines for Self-Compacting Concrete. The European Federation of Specialist Construction Chemicals and Concrete Systems. United Kingdom.

[15] The European Federation of Concrete Admixture Associations: EFCA 2005. (2005). The European Guidelines for Self-Compacting Concrete. The European Federation of Concrete Admixture Associations. United Kingdom. 